\title{
DAMPAK PSIKOLOGIS \\ TINDAK PIDANA KEKERASAN SEKSUAL TERHADAP PEREMPUAN
}

Oleh:

\author{
Dies Nurhayati \\ (e-mail: visibos@yahoo.com) \\ Dosen STKIP PGRI Pasuruan \\ JI. Ki Hajar Dewantoro No. 27 - 29 Telp. (0343) 421948 PASURUAN - 67118
}

\begin{abstract}
In Indonesia, criminal acts are so various, especially which place women as the victims. One of the forms or frightening criminal acts through women is sexual violence. Sexual violence that undergoes women frequently is classified to the serious human rights colliding or extra ordinary crime which not only causes physical suffer but also causes educational and psychological looses through the victims. The victims (women) have suffered layered suffers due to sexual violence suffering. By sexual violence, women have been conducted as the subordination of the men biological capacity, besides his threatening educational future.
\end{abstract}

Keyword: sexual violence, victims, human rights

Berbagai bentuk kekerasan yang bercorak sebagai penindasan terhadap perempuan di Indonesia ini bermacammacam, yang mengesankan kalau sampai sekarang, perempuan masih saja diperlakukan sebagai obyek praktikpraktik yang terpuji dan tidak memartabatkan dirinya.

Penindasan terhadap perempuan menyebabkan korbannya sangat menderita secara kuantitatif dan kualitatif (psikologis. Akan tetapi, penderitaan ini acapkali tidak terkenali sebagai prasangka negatif menurut acuan jenis kelamin dari pihak yang tertindas (perempuan) dan yang menindas (lakilaki) bahwa hal tersebut sudah merupakan suatu kewajaran yang alami. (Aina Fitalaya F. Hubbes, 1997: 23) Salah satu bentuk penindasan yang dilakukan oleh kaum laki-laki terhadap perempuan adalah tindak pidana kekerasan. Tindak pidana kekerasan itu membuat perempuan menanggung beban secara fisik maupun psikologis. Kekerasan yang menimpanya bukan hanya men-ciptakan ketidakberdayaan, tetapi juga merampas hak-hak psikologisnya, seperti ketenangan, kedamaian, dan bebas dari rasa takut. (Bambang S, 2005:4)

Kekerasan yang menimpanya ini menjadi cermin kalau dirinya belum diperlakukan sebagai subyek yang bermartabat dan humanistik. (Abdul Halim, $2004: 3)$

Dalam hidup ini, perempuan membutuhkan suasana damai, menyenangkan dan perlakuan yang tidak menyakiti, tidak sewenang-wenang dan tidak membuatnya hidup dalam penderitaan secara fisik 
maupun non-fisik. Kalau perempuan masih hidup dalam suasana dan perlakuan demikian, berarti belum bisa dikatakan sebagai manusia yang terjamin hak fundamentalnya di bidang pemanusiaan dirinya.

\section{Perempuan di Negara Hukum}

Seharusnya secara normatif, perempuan yang hidup dalam negara hukum adalah pihak yang paling berbahagia, karena pola hidup dan berinteraksi sosial, budaya, politik, dan aspek-aspek lainnya sudah diatur oleh peraturan perundang-undangan yang memberikan jaminan secara positip terhadap hak-hak asasinya (HAM). (Bambang S, 2005:5)

Dijelaskan Wasis Suprayitno, bahwa memahami esensi hak asasi manusia (HAM), tidak lepas dari konteks sejarahnya. Ketika Deklarasi Hak Asasi Manusia (human rights) menggaung di gedung PBB, pada saat yang sama kondisi negara-negara di dunia sedang "lesu darah" akibat perang. Beruntung di tengah-tengah kelesuan itu, masih tersisa kesadaran tentang pentingnya menghargai nilai kemanusiaan. Munculnya Deklarasi Hak Asasi Manusia dan beberapa kovenan tentang hak asasi manusia, setidaknya sebagai bukti adanya kesadaran itu. Kendati jauh sebelumnya, embrio kelahiran Deklarasi Hak Asasi manusia muncul abad 13 yang silam, Magna Charta, Bill of Rights versi Inggris dan Amerika serta Declaration des droits delhomme et du Citoyen-nya Perancis setidaknya perintis kemunculan isu hak asasi mansia itu. Paparan ini tidak hanya terletak pada aspek historisnya, melainkan pada roh atau jiwa yang paling esensial dari Hak Asasi Manusia (HAM), artinya faktor "memanusiakan manusia" harus paling dikedepankan guna menghormati dan memartabatkan manusia. Pelecehan hak-hak asasi manusia pada dasarnya menentang kodrat manusia. (Kusbandiah, 2003: 3)

Praktik memanusiakan manusia, terutama perempuan itu menjadi tanggung jawab utama negara melalui peraturan perundang-undangan yang dibuatnya. Tugas negara ini sama artinya dengan mengimplementasikan per-lindungan hak asasi perempuan melalui hukum, artinya di dalam hukum itu terumus ketentuan yang memerintahkan perlindungan hak asasi perempuan.

Eksistensi dan diskursus tentang hak asasi manusia adalah setua usia kehidupan dan dinamika sejarah pergulatan manusia itu sendiri. Ketika ada konflik dan pelanggaran norma hukum berskala mikro maupun makro, regional, nasional maupun internasional, bersifat individu, kelompok maupun kelembagaan, maka persoalan hak asasi seringkali ditampilkan sebagai prioritas baik dalam kepentingan 
sebatas responsi maupun strategi perlindungan dan advokasinya. (MuhammatTholhah Hasan, 2001: 62)

Baharuddin Lopa juga menyebut kan, bahwa semua hak asasi manusia sesudah perang Dunia II (sesudah Hitler memusnahkan berjuta-juta manusia) adalah dijadikan dasar pemikiran untuk melahirkan rumusan mengenai Hak Asasi Manusia (HAM) yang bersifat universal, yang kemudian dikenal dengan The Universal Declaration of Human Rights yang diciptakan oleh PBB. (Baharuddin Lopa, 1996: 4)

Pendapat tersebut merupakan peringatan agar hak-hak asasi perempuan dijunjung tinggi oleh siapapun makhluk hidup di muka bumi. Pengalaman bersejarah sudah mengajarkan, bahwa setiap bentuk pelanggaran hak perempuan, apapun nama dan jenisnya layak dikategorikan sebagai bentuk perampasan, pelecehan, dan penindasan terhadap martabat perempuan.

Kekerasan seksual (sexual violence) yang banyak menimpa perempuan akhir-akhir ini juga tergolong sebagai pelanggaran HAM yang serius atau sebagai kejahatan istimewa yang bukan hanya menimbulkan derita fisik, tetapi telah mengakibatkan derita psikologis yang berat kepada korban. Korban (perempuan) telah mengalami penderitaan secara berlapis akibat kekerasan seksual yang menimpanya.

\section{Hak Diperlakukan Secara Manusiawi}

Salah satu hak warga (manusia) yang dijamin oleh negara adalah hak untuk tidak diperlakukan secara tidak manusiawi. Manusia seharusnya tidak menjadikan sesamanya sebagai korban perilakuperilakunya yang bermodus kriminalitas seperti tindak kekerasan. Sebab, manusia sudah hidup di negara hukum yang segala perilakunya harus sesuai dan akan di pertanggungjawabkan secara hukum tanpa kecuali jika melakukan pelanggaran hukum.

Di dalam pasal 28-B ayat (2) Undang-undang Dasar 1945 setelah Amandemen Kedua Tahun 2000 juga menyebutkan, bahwa setiap orang berhak atas kelangsungan hidup, tumbuh, dan berkembang serta berhak atas perlindungan dari kekerasan dan diskriminasi.

Ketentuan dalam konstitusi tersebut menunjukkan prinsip egaliter dalam perlindungan harkat dan martabat manusia, tidak boleh ada perbedaan atau perlakuan yang mendiskriminasikan antara laki dan perempuan atau atas dasar alasan dan kepentingan gender. Kata "setiap orang berhak" menjadi dasar pembenarnya kalau perlindungan hukum tidak mengenal perbedaan status sosial, politik, dan jenis kelamin. Baik laki-laki maupun perempuan harus diperlakukan 
secara sederajat atau tidak dibedakan, misalnya lelaki tidak diperlakukan lebih istimewa dan superior dibandingkan perempuan di dalam sistem hukum yang berlaku.

Di dalam konstitusi tersebut juga menunjukkan bahwa setiap orang harus dijauhkan atau dijaga dari kemungkinan menjadi korban berbagai bentuk aksi atau perilaku yang bermodus kekerasan seperti tindakan kejam dan tidak bermartabat kepada orang lain. Setiap orang, termasuk di dalamnya adalah perempuan harus dilindungi harkat dan martabatnya dari tindak kekerasan.

Pemikiran itu memberikan garis ideal yang menentukan kalau perempuan harus mendapatkan suasana yang kondusif dari negara yang menghormati hakhak asasinya atau menyelamatkan dirinya dari kemungkinan menjadi objek terjadinya tindak kekerasan yang terjadi di tengah kehidupan bermasyarakat maupun bernegara.

Perlindungan terhadap hak-hak asasi perempuan itu menjadi kewajiban negara. Ifdal Kasim menyebutkan, bahwa tugas negara dalam kaitannya dengan HAM setidaknya ada tiga, pertama adalah dalam bentuk menghormati (obligation to respect), kedua, dalam bentuk melindungi (obligation to protect), dan ketiga, dalam bentuk pemenuhan (obligation to fulfil). Dalam hak asasi manusia internasional, negara adalah faktor utama yang memegang kewajiban dan tanggungjawab (duty holders). Sementara individu (termasuk juga kelompok dan "rakyat") berkedudukan sebagai pemegang hak (right holders). (Eko Prasetyo, 2001 : 4445).

Paparan itu menunjukkan bahwa tugas negara berkaitan dengan penegakan hak asasi manusia (HAM) adalah sangat fundamental, mengingat dalam tugasnya itu setidaknya menyangkut implementasi tiga aspek, yaitu penghormatan, perlindungan dan pemenuhan hak-hak asasi manusia (HAM). Ketiga aspek ini sangat menentukan apakah manusia dapat hidup sejahtera dan bahagian lahir batin ataukah tidak.

Untuk menjembatani ketiga tugas negara tersebut, negara melalui institusi yang dipercaya memerintahkan untuk membuat peraturan perundang-undangan yang dinilai bisa menjawab problem yang dihadapi rakyat (manusia). Pemegang hak misalnya akan memiliki jaminan kepastian atas haknya bilamana kekuatan hukum diperankan untuk melindungi, membela atau memperjuangkannya.

Di dalam rumusan hukum itulah hakhak manusia diaturnya, setidaknya bisa dipertanyakan eksistensinya, termasuk ketika dihubung-kan dengan problem kriminalitas. Hak perempuan pun diatur dalam hukum sebagai suatu bentuk 
jaminan perlindungan dari perlakuan yang tidak memanusiakannya. Penderitaan korban, apapun jenis penderitaan yang dialaminya layak dikategorikan sebagai bagian dari produk pelanggaran HAM.

\section{Pengaturan Tindak Pidana Kekerasan Seksual}

Pancasila sebagai dasar falsafah negara dan Undang-undang Dasar 1945 memberikan hak kepada setiap warga negara untuk mendapatkan rasa aman dan bebas dari segala bentuk kekerasan, karena merupakan pelanggaran hak asasi manusia dan merupakan kejahatan terhadap martabat kemanusian.

Istilah kekerasan secara rinci didefinisikan dalam Undang-undang No 23 Tahun 2004, sedangkan secara umum diatur dalam Kitab Undang-undang Hukum Pidana. Undang-undang No 23 Tahun 2004 tentang Penghapusan Kekerasan Dalam Rumah Tangga mendefinisikan kekerasan dalam rumah tangga adalah setiap perbuatan terhadap seseorang terutama perempuan, yang berakibat timbulnya kesengsaraan atau penderitaan secara fisik, seksual, psikologis, dan / atau penelantaran rumah tangga termasuk ancaman untuk melakukan perbuatan, pemaksaan, atau perampasan kemerdekaan secara melawan hukum dalam lingkup rumah tangga. Kekerasan menurut Undang- undang No 23 Tahun 2004 meliputi: a. Kekerasan fisik, kekerasan psikis, kekerasan seksual, dan penelantar-an rumah tangga. Kekerasan fisik adalah perbuatan yang meng-akibatkan rasa sakit, jatuh sakit, atau luka berat. Kekerasan psikis adalah perbuatan yang mengakibatkan ketakutan, hilangnya rasa percaya diri, hilangnya kemampuan untuk bertindak, rasa tidak berdaya, dan / atau penderitaan psikis berat pada seseorang.

Kekerasan seksual dalam Undangundang No 23 Tahun 2004 meliputi: 1. pemaksaan hubungan seksual yang dilakukan terhadap orang yang menetap dalam lingkup rumah tangga tersebut. 2 . pemaksaan hubungan seksual terhadap salah seorang dalam lingkup rumah tangganya dengan orang lain untuk komersial dan / atau tujuan tertentu.

Definisi atau pengertian kekerasan seksual secara eksplisit dijelaskan dalam Undang-undang No 23 Tahun 2004, namun secara umum Kitab Undangundang Hukum Pidana sebagai induk dari peraturan perundang-undangan pidana di Indonesia, mengklasifikasikan kekerasan seksual ke dalam rumpun kejahatan kesusilaan, yang tercantum dalam Bab XIV Kitab Undang-undang Hukum Pidana pasal 281 sampai dengan pasal 303 bis.

Kekerasan seksual dalam Kitab Undang-undang Hukum Pidana berlaku secara umum, dan dengan adanya 
Undang-undang No 23 Tahun 2004 tentang Penghapusan Kekerasan Dalam Rumah Tangga, maka kekerasan seksual yang terjadi dalam lingkup rumah tanga tidak lagi dikenakan Kitab Undangundang Hukum Pidana, tetapi Undangundang No 23 Tahun 2004.

Kitab Undang-undang Hukum Pidana tidak menjelaskan secara rinci pengertian kekerasan, namun membuat orang pingsan atau tidak berdaya disamakan dengan menggunakan kekerasan sebagaimana diatur dalam pasal 89 Kitab Undang-undang Hukum Pidana.

Beberapa pasal dalam Kitab Undang-undang Hukum Pidana yang mengatur tentang kekerasan seksual adalah pasal 285, 286, 287, 288, 289, 290, 291, 292, 293, 294, 295 Kitab Undangundang Hukum Pidana.

Pasal 285 Kitab Undang-undang Hukum Pidana menyebutkan bahwa, barangsiapa dengan kekerasan atau ancaman kekerasan memaksa seorang wanita bersetubuh dengan dia di luar perkawinan, diancam karena melakukan pemerkosaan dengan pidana penjara paling lama dua belas tahun.

Pasal 286 Kitab Undang-undang Hukum Pidana menyebutkan bahwa, barangsiapa bersetubuh dengan seorang wanita di luar perkawinan, padahal diketahui bahwa wanita itu dalam keadaan pingsan atau tidak berdaya, diancam dengan pidana penjara paling lama sembilan tahun.

Pasal 287 Kitab Undang-undang Hukum Pidana menyebutkan bahwa (1) barangsiapa bersetubuh dengan seorang wanita di luar perkawinan, padahal diketahui atau sepatutnya harus diduga bahwa umurnya belum lima belas tahun, atau kalau umurnya belum ternyata bahwa belum mampu dikawin, diancam dengan dengan pidana penjara paling lama sembilan tahun. (2) penuntutan hanya dilakukan atas pengaduan, kecuali jika umurnya wanita belum sampai dua belas tahun atau jika ada salah satu hal tersebut dalam ketentuan pasal 291 dan ketentuan pasal 294.

Pasal 288 Kitab Undang-undang Hukum Pidana menyebutkan bahwa (1) barangsiapa bersetubuh dengan seorang wanita di dalam pernikahan, yang diketahui atau sepatutnya harus diduga bahwa sebelum mampu dikawin, diancam, apabila perbuatan mengakibatkan lukaluka, dengan pidana penjara paling lama empat tahun. (2) Jika perbuatan mengakibatkan luka-luka berat, dijatuhkan pidana penjara paling lama delapan tahun. (3) Jika mengakibatkan mengakibatkan mati dijatuhkan pidana penjara paling lama dua belas tahun.

Pasal 289 Kitan Undang-undang Hukum Pidana menyebutkan bahwa 
barangsiapa dengan kekerasan atau ancaman kekerasan memaksa seseorang untuk melakukan atau membiarkan dilakukan perbuatan cabul, diancam karena melakukan perbuatan yang menyerang kehormatan kesusilaan, dengan pidana penjara paling lama sembilan tahun.

Pasal 290 Kitab Undang-undang Hukum Pidana menyebutkan bahwa diancam dengan pidana penjara paling lama tujuh tahun, kesatu, barangsiapa melakukan perbuatan cabul dengan seorang padahal diketahui bahwa orang tu pingsan atau tidak berdaya, kedua, barangsiapa melakukan perbuatan cabul dengan seorang padahal diketahui atau sepatutnya harus diduga bahwa umurnya belum lima belas tahun atau kalau umurnya tidak ternyata bahwa belum mampu dikawin, ketiga, barangsiapa membujuk seseorang yang diketahui atau sepatutnya harus diduga bahwa umurnya belum lima belas tahun atau umurnya tidak ternyata bahwa belum mampu dikawin, untuk melakukan atau membiarkan dilakukan perbuatan cabul atau bersetubuh di luar perkawinan dengan orang lain.

Pasal 291 Kitab Undang-undang Hukum Pidana menyebutkan bahwa (1) Jika salah satu kejahatan yang diterangkan dalam pasal 286, 287, 289, dan 290 mengakibatkan luka-luka berat, dijatuhkan pidana penjara paling lama dua belas tahun (2) Jika salah kejahatan yang diterangkan dalam pasal 285, 286, 287, dan 290 itu mengakibatkan mati dijatuhkan pidana penjara paling lama lima belas tahun.

Pasal 292 Kitab Undang-undang Hukum Pidana menyebutkan bahwa orang yang belum cukup umur yang melakukan perbuatan cabul dengan orang lain sama kelamin, yang diketahui atau sepatutnya harus diduga bahwa belum cukup umur, diancam dengan pidana penjara paling lama lima tahun.

Pasal 293 Kitab Undang-undang Hukum Pidana menyebutkan bahwa (1) barangsiapa dengan memberi atau menjanjikan uang atau barang, menyalahgunakan perbawa yang timbul dari hubungan keadaan atau dengan penyesatan sengaja menggerakkan seorang belum cukup umur dan baik tingkah lakunya, untuk melakukan atau membiarkan dilakukan perbuatan cabul dengan dia, padahal tentang belum cukup umurnya itu diketahui atau selayaknya harus diduga, diancam dengan pidana penjara paling lama lima tahun. (2) Penuntutan hanya dilakukan atas pengaduan orang yang terhadap dirinya dilakukan kejahatan itu. (3) Tenggang tersebut dalam pasal 74 , bagi pengaduan ini adalah masing-masing 
sembilan bulan dan dua belas bulan.

Pasal 294 Kitab Undang-undang Hukum Pidana menyebutkan bahwa (1) barangsiapa melakukan perbuatan cabul dengan anaknya, anak tirinya, anak angkatnya, anak dibawah pengawasannya, yang belum cukup umur, atau dengan orang yang belum cukup umur yang pemeliharaannya, pendidikan atau penjaaannya diserahkan kepadanya ataupun dengan bujangnya atau bahawannya yang belum cukup umur, diancam dengan pidana penjara paling lama tujuh tahun. (2) Diancam dengan pidana yang sama, kesatu, pejabat yang melakukan perbuatan cabul dengan rang yang karena jabatan adalah bawahannya, atau dengan orang yang penjagaannya dipercayakan atau diserahkan kepadanya, kedua, seorang pengurus, dokter, guru, pegawai, pengawas atau pesuruh dalam penjara, tempat pekerjaan negara, tempat pendidikan, rumah piatu, rumah sakit, rumah sakit ingatan atau lembaga sosial, yang melakukan perbuatan cabul dengan orang yang dimasukkan ke dalamnya.

Pasal 295 Kitab Undang-undang Hukum Pidana menyebutkan bahwa (1) diancam, kesatu, dengan pidana penjara paling lama lima tahun, barangsiapa dengan sengaja menghubungkan atau memudahkan dilakukannya perbuatan cabul oleh anaknya, anak tirinya, anak angkatnya, atau anak di bawah pengawasannya yang belum cukup umur, atau oleh orang yang belum cukup umur yang pemeliharaannya, pendidikan atau penjagaannya diserahkan kepadanya ataupun oleh bujangnya atau bawahannya yang belum cukup umur, dengan orang lain, kedua, dengan pidana penjara paling lama empat tahun, barangsiapa dengan sengaja menghubungkan atau memudah-kan perbuatan cabul kecuali tersebut kesatu di atas yang dilakukan oleh orang yang diketahui belum cukup umurnya atau yang sepatutnya harus diduga demikian dengan orang lain. (2) jika yang bersalah melakukan kejahatan itu sebagai pen-caharian atau kebiasaan, maka pidana dapat ditambah sepertiga.

Dari beberapa pasal yang tercantum dalam Kitab Undang-undang Hukum Pidana tentang tindak pidana kekerasan seksual dilakukan melalui kekerasan fisik maupun kekerasan psikis. Tindak pidana kesusilaan yang dilakukan terhadap anak belum cukup umur merupakan bentuk ketidakberdayaan korban.

\section{Dampak Psikologis terhadap Korban}

Dikatakan Sudarto, bahwa kejahatan merupakan suatu gejala yang menyangkut setiap orang. Kejahatan berkisar dari bentuk yang ringan hingga yang keji (berat) seperti kekerasan yang 
mengakibatkan timbulnya problem fisik maupun non-fisik. Namun harus disadari bahwa yang melakukan kejahatan itu juga orang seperti kita. Kejahatan memang harus ditanggulangi karena mendatangkan ketidaktentraman dalam kehidupan masyarakat, maka kita perlu menerapkan cara-cara yang rasional dalam penanggulangannya. (Abdul Wahid, 2000:14)

Pernyataan Sudarto tersebut menunjukkan kalau kejahatan itu di satu sisi dapat memenuhi kesenangan (kepentingan) pelakunya, namun di sisi lain kejahatan itu, khususnya tindak kejahatan dengan kekerasan adalah berdampak buruk pada diri korban baik secara fisik maupun non-fisik. Dalam kondisi demikian, sangat tjelas kalau seseorang menjadi korban tindak kejahatan itu berarti menjadi korban atas pelanggaran hak-hak asasi manusia.

Fenomena Pelanggaran hak asasi manusia (HAM) itu dapat terlihat pada potret kehidupan perempuan Indonesia, yang menempati komunitas yang paling rawan menjadi korban tindak kejahatan di bidang ekonomi dan politik. Di berbagai tindak kejahatan yang tergolong menjadi wacana publik dan bahkan mengundang keprihatinan nasional, perempuanlah yang seringkali menjadi dan dijadikan sebagai korbannya. Perempuan belum diperlakukan oleh kaum lelaki sebagai subjek yang dimartabatkan dan bukan menjadi objek yang dikorban demi kepentingan ekonomi, politik, budaya, kepuasan biologis, dan lain sebagainya. Perempuan masih belum mendapatkan perlindungan yang memadai. Terbukti, masih banyaknya perlakuan yang tidak menghormati harkat kemanusiaan perempuan.

Hillary Clinton dalam KTT Pembangunan Sosial di Kopenhagen (1996) mengungkapkan, bahwa 70\% dari 1,2 miliar manusia miskin adalah wanita, sekitar 550 juta pekerja wanita mendapatkan penghasilan per kapita di bawah standar kemiskinan PBB 370 dolar. $75 \%$ dari jumlah itu adalah buta huruf. Lebih mengerikan lagi, 2 juta wanita di dunia telah menjadi korban pelanggaran seksual. Belum ditambah jutaan wanita yang tidak mendapatkan akses pendidikan, kesehatan, kehidupan sosial yang layak, keadilan hukum dan perlindungan hak-hak asasinya. Demikian pula sekitar 550 juta perempuan pekerja berpenghasilan di bawah garis kemiskinan PBB: 370 dolar, ditambah laju kemiskinan perempuan lebih tinggi dibandingkan pria, padahal jumlah penduduk perempuan hampir separoh (52\%) dari penduduk dunia. (Dadang S. Anshari (et.al), 1997 :12)

Penjelasan yang diuraikan Hillary Clinton itu dapat dijelaskan lebih lanjut, 
bahwa posisi perempuan di di berbagai aspek kehidupan ini belum menunjukkan keberdayaannya, artinya nasib dan kedudukan perempuan secara yuridis, politik, budaya, ekonomi, dan lainnya masih belum sebaik dibandingkan dengan kedudukan kaum lelaki. Kaum lelaki masih berstrata sosial lebih baik dibandingkan dengan perempuan.

Perempuan di berbagai kegiatan yang bersifat ekonomi, seperti di au lapangan kerja masih belum menempati posisi sebagai subjek yang butuh dihormati hak-hak asasinya. Mereka (perempuan) masih sebatas sebagai objek pemenuhan kepentingan yang bertentengan dengan norma-norma moral dan hukum. Salah satu problem yang dihadapi perempuan di sektor ekonomi ini adalah ancaman dan tindakan kekerasan seksual (sexual violence) atau pelecehan seksual (sexual harassement).

Kondisi kemiskinan perempuan misalnya dinilai sebagai salah satu problem sosial yang mengakibatkan perempuan kesulitan menunjukkan keberdayaannya tatkala dihadapkan dengan ancaman atau tindakan-tindakan yang mengorbankannya atau melecehkan hak asasinya. Adanya ketergantungan ekonomi yang sangat parah dapat menjadi salah satu faktor yang mengakibatkan perempuan secara psikologis kesulitan melakukan perlawanan dan menolak berbagai bentuk perilaku yang melecehkan hak asasi perlindungan seksualnya, di samping hak-hak lainnya.

Di Indonesia, menurut data Survey Angkatan Kerja Nasional 1990, sekitar $61,21 \%$ dari 6,621 pekerja perempuan berpenghasilan kurang dari 50 ribu rupiah/bulan. Sedangkan kaum lelaki yang berpenghasilan sama hanya $24,83 \%$. Belum ditambah berbagai kasus dan persoalan buruh perempuan lainnya, upah perempuan yang diskriminatif dengan lelaki, pelecehan seksual di tempat kerja, eksploitasi dan kekerasan seksual melalui TKW (Tenaga Kerja Wanita), sampai hak cuti haid dan melahirkan bagi pekerja perempuan. Semua hal di atas masih tidak menguntungkan kelompok gender ini. (Dadang S. Anshari (et.al), 1997 :2)

Pendapat itu menunjukkan, bahwa masih ada ketidak-adilan gender di Indonesia selama ini. Soal ketidak-adilan gender ini, dijelaskan oleh Mansour Faqih, bahwa perbedaan gender sesungguhnya tidaklah menjadi masalah sepanjang tidak melahirkan ketidakadilan gender (gender inequalities). Namun yang menjadi persoalan, ternyata perbedaan gender telah melahirkan berbagai ketidakadilan, baik bagi kaum laki-laki maupun (khususnya) perempuan. Ketidakadilan gender merupakan sistem dan struktur di mana baik kaum laki-laki dan perempuan menjadi korban dari sistem tersebut. Untuk 
memahami ketidakadilan gender dapat dilihat melalui pelbagai manifestasi ketidakadilan yang ada. Marginalisasi atau proses pemiskinan ekonomi, subordinasi atau anggapan tidak penting dalam keputusan politik, pembentukan stereotip atau melalui pelabelan negatif, kekerasan (violence), beban kerja lebih panjang dan lebih banyak (burden), serta sosialisasi ideologi nilai peran gender.( Mansour Faqih, 1996 :12-13)

Data seperti itu juga menjelaskan bahwa kehidupan perempuan Indonesia juga masih menghadapi problem yang serius di berbagai segi kehidupannya. Salah satu problem yang dihadapi perempuan Indonesia adalah perlakuan yang tidak manusiawi, sewenangwenang, dan kejam yang ditujukan kepadanya. Misalnya ketika laki-laki tidak atau gagal mengendalikan nafsu seksualnya, salah satu bentuk penyalurannya secara immoral dan bertentangan secara yuridis adalah menjadikan perempuan itu sebagai objek pemaksaan kehendaknya dalam bentuk persetubuhan paksa. Sedangkan setiap bentuk pemaksaan niscaya meng-akibatkan penderitaan fisik maupun psikologis.

Hal itu menunjukkan bahwa di negeri ini masih marak kasus yang menempatkan perempuan sebagai korban utamanya. Mereka (perempuan) itu menjadi korban secara berlapis atau berlipat ganda. Setelah menjadi korban pertama, dilanjutkan untuk mengorbankan yang kedua kalinya, dan seterusnya. Misalnya ada kasus yang seringkali melibatkan perempuan menjadi korbannya secara berlapis, umpamanya perempuan menyukai seorang lelaki, tapi kemudian ditipu dan dihabiskan harta bendanya setelah lebih dulu perempuan itu diperkosa. Sehabis diperkosa, perempuan itu dikawini, dan setelah dikawini, perempuan itu dijual kepada orang lain.

Anak-anak dan perempuan memang selalu menjadi korban dalam setiap konflik. Lebih-lebih anak perempuan, mereka menjadi sasaran yang menjadi korban perkosaan. Di Aceh misalnya, anak-anak perempuan kebanyakan menjadi korban pelecehan seksual, perkosaan, dan perkosaan oleh tentara. Pengungsian besar-besaran di wilayah itu mengakibatkan anak-anak di kamp-kamp pengungsian terserang berbagai penyakit. Banyak perempuan hamil yang melahirkan dengan fasilitas seadanya. Sejumlah anakanak dan perempuan lanjut usia meninggal karena kondisi sanitasi yang buruk.

Diah Kartika Sari memberikan komentar, bahwa berbagai bentuk kampanye, lewat dialog publik, seminar, peny uluhan, dan lain-lain telah diluncurkan. Namun sampai hari ini kekerasan terus berlanjut, sebab sangat sedikit korban yang mau mengungkap- 
kannya. Hal ini menyebabkan banyak pihak sulit mempercayai bahwa kekerasan itu memang nyata dan membutuhkan upaya nyata pula untuk membantu korban dan mencegah bertambahnya korban. Trauma kejiwaan telah menjadi kenyataan yang menyiksa diri korban secara mendalam, berlapis, dan berjangka waktu lama. Hal ini menunjukkan, bahwa penderitaan perempuan secara psikologis bagi perempuan yang menjadi korban kekerasan seksual tergolong serius atau tidak bisa dianggap ringan.

Realitas memprihatinkan cukup banyak terjadi di Indonesia, khususnya yang berhubungan dengan hak perempuan. Perkembangan perlindungan atau penegakan hal asasi perempuan dari waktu ke waktu semakin banyak menghadapi ujian, karena banyaknya atau beragamnya perlakuan buruk yang dialami perempuan. Salah satu bentuk perlakuan buruk terhadap perempuan kekerasan seksual. Kasus ini telah membuat perempuan banyak kehilangan hak-haknya.

Kekerasan seksual (sexual violence) yang banyak menimpa perempuan dewasa ini ini tergolong sebagai pelanggaran hak asasi mansia yang serius atau sebagai kejahatan istimewa (exstra ordinary crime) yang bukan hanya menimbulkan derita fisik, tetapi telah mengakibatkan derita psikologis yang berat kepada korban, di samping perempuan menghadapi kegagalan atau ketertundaan dalam melanjutkan hak kependidikannya.

Dengan kekerasan seksual yang dilakukan kaum lelaki, perempuan telah diperlakukan sebagai subordinasi atau "warga klas dua" dari kepentingan biologisnya. Perempuan masih tidak ubahnya sebagai obyek yang dianggap wajar oleh sikap dan perilaku laki-laki yang sedang kehilangan naluri kemanusiaannya atau komitmennya dalam memartabatkan perempuan.

\section{DAFTAR PUSTAKA}

Abdul Halim, Membaca Perempuan Indonesia (Perspektif Multidimensi), Visimedia Bangsa, Jakarta, 2004

Abdul Wahid, Kriminologi dan Kejahatan Kontemporer, Visipres, Surabaya, 2000

Bambang S, Dampak Kejiwaan Perlakuan Kekerasan Seksual terhadap Anak Perempuan,

Baharuddin Lopa, Al-Qur'an dan Hak Asasi Manusia, Jakarta, 1996.

Dadang S. Anshari (et.al), Membincang Feminisme, Pustak Hidayah, Bandung, 1997.

Kusbandiah, Perlindungan Hak Asasi Korban Kekerasan Seksual, Buana,2003.

Made Darma Weda, Kriminologi, Rajagrafindo persada, Jakarta, 1996. 
Mahmudi, Sisi Lain dari Derita Perempuan Akibat Kekerasan Seksual, Hasil Penelitian yang dipaparkan di Yayasan Permata Hati, 23 Juli 2005

Mansour Faqih, Gender dan Transformasi Sosial, Pustaka Pelajar, Yogyakarta, 1996
Muhammat Tholhah Hasan (et.al.), Penegakan HAM di Indonesia, Pusat Studi Hak Asasi ManusiaBKBH Unisma Malang, 2001 